(c) American Dairy Science Association, 2007.

\title{
Ruminal Lipopolysaccharide Concentration and Inflammatory Response During Grain-Induced Subacute Ruminal Acidosis in Dairy Cows
}

\author{
G. N. Gozho, D. O. Krause, and J. C. Plaizier ${ }^{1}$ \\ Department of Animal Science, University of Manitoba, Winnipeg, Manitoba, Canada R3T 2N2
}

\begin{abstract}
The effects of grain-induced subacute ruminal acidosis (SARA) in lactating dairy cows on free ruminal lipopolysaccharide (LPS) and indicators of inflammation were determined. Four mid lactation dairy cows were divided into 2 groups of 2 cows and used in a repeated switchover design. During each period, SARA was induced in 2 animals for 5 subsequent days by replacing $25 \%$ of their total mixed ration (dry matter basis) with a concentrate made of 50\% wheat and 50\% barley. The other 2 cows acted as controls and were fed a total mixed ration diet in which $44 \%$ of dry matter was concentrate. On average, inducing SARA did not affect milk composition, increased the duration of rumen $\mathrm{pH}$ below 5.6 from 187 to $309 \mathrm{~min} / \mathrm{d}$, and increased free ruminal LPS concentration from 24,547 endotoxin units (EU)/mL to $128,825 \mathrm{EU} / \mathrm{mL}$. Averaged across treatments, milk fat yield and milk protein yield were 0.66 and $1.00 \mathrm{~kg} / \mathrm{d}$, respectively. Rumen $\mathrm{pH}$ and milk fat data suggest that control cows also experienced ruminal acidosis, albeit a milder form of this disease than SARA cows. Serum LPS concentration in both control and SARA cows was less than the detection limit of $<0.01 \mathrm{EU} / \mathrm{mL}$ for the assay. Induction of SARA elevated serum amyloid A concentration from 286.8 to $498.8 \mu \mathrm{g} / \mathrm{mL}$, but did not affect other markers of inflammation including haptoglobin, fibrinogen, serum copper, or white blood cells. These results suggest that grain-induced SARA in mid lactation dairy cows increases the lysis of gram-negative bacteria and activates an inflammatory response.
\end{abstract}

Key words: subacute ruminal acidosis, lipopolysaccharide, serum amyloid A, haptoglobin

\section{INTRODUCTION}

Subacute ruminal acidosis (SARA) is a common health problem in high-yielding dairy cattle (Nordlund et al., 1995; Garrett et al., 1997), but data to quantify

Received April 13, 2006.

Accepted September 7, 2006.

${ }^{1}$ Corresponding author: plaizier@ms.umanitoba.ca associated losses are scarce. A case study of a 500-cow herd in New York State estimated losses due to SARA to be $\$ 1.12$ per cow per day (Stone, 1999). Losses that are attributed to SARA include decreased milk yield, reduced milk fat, a general loss in efficiency of milk production, and increased culling due to lameness (Nocek, 1997; Stone, 1999).

An earlier study by our group (Gozho et al., 2005) showed that abrupt induction of SARA (by feeding wheat barley pellets and chopped alfalfa hay in separate meals so that the concentrate inclusion in the diets ranged from 47 to $56 \%$ DM in steers that had previously been adapted to a forage diet) increased free ruminal LPS, serum amyloid A (SAA), and haptoglobin (Hp) in peripheral blood from 3,714 to 12,589 endotoxin units $(\mathbf{E U}) / \mathrm{mL}$, from 33.6 to $170.7 \mu \mathrm{g} / \mathrm{mL}$, and from 0.43 to $0.79 \mathrm{mg} / \mathrm{mL}$, respectively. A subsequent study from our group showed that gradual adaptations to a $60 \%$ concentrate diet over a 4 -wk period followed by grain-induced SARA increased free ruminal LPS, SAA, and Hp from 6,542 to 32,275 EU/mL, from 36.5 to $131.3 \mu \mathrm{g} / \mathrm{mL}$, and from 0.54 to $2.39 \mathrm{mg} / \mathrm{mL}$, respectively (Gozho et al., 2006). It has been suggested that low rumen $\mathrm{pH}$ could result in death and lysis of gram-negative bacteria and hence increase free LPS in the rumen (Nagaraja et al., 1978; Andersen et al., 1994). However, there is evidence showing that free ruminal LPS can also result from bacterial cell lysis due to excessive autolytic enzymes that facilitate growth during the rapid bacterial growth phase (Wells and Russell, 1996).

Inducing acute acidosis in 2 Jersey cows that had been adapted to a hay-based diet increased the bacterial endotoxin activity from 9.1 and $9.3 \mu \mathrm{g} / \mathrm{mL}$ to 143.3 and $172 \mu \mathrm{g} / \mathrm{mL} 12 \mathrm{~h}$ after grain engorgement (Nagaraja et al., 1978). Andersen et al. (1994) also reported numerical increases in free ruminal LPS only in cows that had been adapted to grain-based compared with hay-based diets when rumen $\mathrm{pH}$ decreased from 6.92 to 5.76. The role of free ruminal LPS in the etiology of diseases related to grain engorgement such as ruminal acidosis, rumenitis, sudden death syndrome, and laminitis is not clearly understood but it has been postulated that increased translocation of free ruminal LPS 
into blood circulation may be an important causative factor (Dougherty et al., 1975; Nagaraja et al., 1978, Andersen et al., 1994).

The role of free ruminal LPS in these diseases remains difficult to ascertain because free LPS is detoxified in the liver and hence is not detectable in peripheral blood circulation (Andersen, 2000). However, the presence of LPS in blood circulation initiates proinflammatory events that culminate in an inflammatory response that often characterizes bacterial infections (Andersen, 2000). The major inflammation markers in cattle are SAA and Hp. Both SAA and Hp have been used as inflammation indicators in studies in which LPS was injected intravenously into cattle (Werling et al., 1996; Jacobsen et al., 2004), or following tissue damage within a localized site (Conner et al., 1988), or other inflammatory diseases in cattle (Alsemgeest et al., 1994). Other indicators of inflammation such as fibrinogen and white blood cells can also be used as markers of inflammation (Arthington et al., 1996; Horadagoda et al., 1999). Fibrinogen shows only a minor increase in response to inflammation in cattle (Hirvonen, 2000) and could play an ancillary role to augment the diagnostic value of acute phase proteins to SARA under field conditions.

The studies from Gozho et al. (2005, 2006) showed that the composition of a concentrate-based diet and duration that the diet is fed before SARA induction affect the changes in free ruminal LPS. High-yielding dairy cows that are fed concentrate-based diets receive a large proportion of their feed as concentrate throughout most of the lactation cycle. As a result, the effects of grain-induced SARA on ruminal free LPS and indicators of inflammation in mid lactation dairy cows might differ from those observed by Gozho et al. (2005, 2006).

The objective of this study was to determine whether inducing SARA in dairy cows in mid lactation affects free ruminal LPS, the concentration of LPS in peripheral blood, SAA, Hp, fibrinogen, serum copper, and white blood cell profiles.

\section{MATERIALS AND METHODS}

\section{Animals and Diets}

Four primiparous, ruminally fistulated Holstein dairy cows were housed in individual tie stalls in the Metabolism Unit of the Glenlea Dairy Research Station (Winnipeg, MB, Canada) in accordance with the guidelines of the Canadian Council of Animal Care (1993). Cows averaged $538 \pm 12.4 \mathrm{~kg}$ of BW and $121 \pm$ 8 (mean \pm SD) DIM with an average milk yield of $30 \pm 4.3 \mathrm{~kg} / \mathrm{d}$ (mean $\pm \mathrm{SD}$ ) at the beginning of the experiment. The experiment was conducted as a re- peated switchover design with 4 periods of 1 wk each. During each period, SARA was induced in 2 cows for only $5 \mathrm{~d}$ (Monday to Friday) using the model developed by Keunen et al. (2002) in which $25 \%$ of the TMR DM intake measured in the previous period was replaced with an equal amount of grain pellets (50\% ground wheat:50\% ground barley) and restricting the availability of TMR between 0900 and $1700 \mathrm{~h}$. During the days that SARA was induced, the SARA cows were offered $2 \mathrm{~kg}$ of TMR whereas control cows were offered their daily allocation of TMR at $0900 \mathrm{~h}$. The amount of pellets fed to each cow during SARA induction averaged $4.4 \pm 0.4$ (mean \pm SD) $\mathrm{kg} / \mathrm{d}$. This amount of pellets increased the proportion of concentrate in the diet to $68 \%$. Pellets were also offered in 2 meals, with $67 \%$ of the daily allocation offered at $1100 \mathrm{~h}$ and the remainder at $1400 \mathrm{~h}$. Two-thirds of the allocation of pellets was offered at $1100 \mathrm{~h}$ to reduce rumen $\mathrm{pH}$ to below 5.6 , whereas the $1400 \mathrm{~h}$ meal was meant to prolong the duration with rumen $\mathrm{pH}$ below 5.6 without further $\mathrm{pH}$ depression.

The daily allocation of TMR for the 2 SARA cows was withheld between 1100 and $1700 \mathrm{~h}$ but was made available to the cows from 1700 to $0800 \mathrm{~h}$ of the following day. The control cows also had access to their daily allocation of TMR from 0900 to $0800 \mathrm{~h}$ of the following day. Treatments were switched in each subsequent week. Cows in both groups had ad libitum access to fresh water. On Saturday at $0900 \mathrm{~h}$, the rumen $\mathrm{pH}$ monitoring equipment was disconnected and cows were taken outside to exercise. On Saturdays and Sundays, all cows were fed only the TMR. The ingredients and chemical composition of the TMR and wheat barley concentrate are given in Table 1. Feed intakes were determined daily and representative feed and orts samples were taken 3 times/wk. Samples were pooled by week and cow, and DM content was determined by oven drying at $60^{\circ} \mathrm{C}$ for $48 \mathrm{~h}$.

\section{Rumen pH, Rumen Fluid, and Rectal Temperature Measurements}

Rumen $\mathrm{pH}$ was measured continuously from Monday at $0900 \mathrm{~h}$ to Saturday at $0900 \mathrm{~h}$ in each period by inserting an indwelling $\mathrm{pH}$ probe into the rumen of each cow as described by Gozho et al. (2005). Rumen $\mathrm{pH}$ was measured at 1-min intervals and data were sent to a data logger for storage and used for subsequent analysis. Rumen $\mathrm{pH}$ data were summarized by calculating average $\mathrm{pH}$, amount of time below $\mathrm{pH} 6$ and $\mathrm{pH} 5.6$, area (time $\times \mathrm{pH}$ ) below $\mathrm{pH} 6$, and area below pH 5.6 for each 24 -h period. Time with rumen $\mathrm{pH}$ below 6.0 was monitored because microbial fiber digestion and nutrient digestibilities are reduced be- 
Table 1. Ingredients and chemical composition of the TMR and wheat-barley pellet concentrate (WBP)

\begin{tabular}{lcc}
\hline Item & TMR & WBP \\
\hline Ingredients, \% of DM & & \\
Alfalfa silage & 32.6 & \\
Oat silage & & \\
Energy supplement $^{1}$ & 22.4 & \\
Protein supplement $^{2}$ & 35.2 & 50.0 \\
Ground wheat & 8.8 & 50.0 \\
Ground barley & & \\
Nutrient composition, \% of DM & & 89.2 \\
DM & 63.4 & 15.5 \\
CP & 18.5 & 17.6 \\
NDF & 31.1 & 5.9 \\
ADF & 23.3 & 62.2 \\
NSC & 37.2 & 0.27 \\
Ca & 1.25 & 0.35 \\
P & 0.53 & 0.56 \\
K & 1.72 & 0.03 \\
Na & 0.36 & \\
\hline
\end{tabular}

${ }^{1}$ Energy supplement contained $54.0 \%$ rolled barley, $15.7 \%$ wheat shorts, $7.7 \%$ canola meal, $6.0 \%$ ground wheat, $4.1 \%$ corn gluten meal, $4.0 \%$ vegetable oil, $2.0 \%$ dried corn distillers grain, $1.9 \%$ soybean meal, $1.48 \%$ calcium carbonate, $0.80 \%$ Dynamate (Mosaic Company, Plymouth, MN), $0.68 \%$ dicalcium phosphate, $0.64 \%$ salt, $0.42 \%$ cane molasses, $0.20 \%$ luprosil salt (calcium propionate), $0.13 \%$ pellet binder, $0.09 \%$ oat hulls, $0.05 \%$ vitamin $\mathrm{ADE}$ premix (vitamin $\mathrm{A}$, 16,800 IU/kg; vitamin D, 2,215 IU/kg; vitamin E, 75 IU/kg, DM basis), $0.05 \%$ trace mineral mix, $0.02 \%$ Se.

${ }^{2}$ Protein supplement contained: $42.0 \%$ dried distillers grain, $7.0 \%$ fish meal, $22.5 \%$ canola meal, $20.0 \%$ soybean meal, $3.2 \%$ beet molasses, $0.3 \%$ niacin, and $5.0 \%$ sodium bicarbonate.

low this rumen $\mathrm{pH}$ (Calsamiglia et al., 2002). Time with rumen $\mathrm{pH}$ below 5.6 was also used because this defines the upper limit of the range of rumen $\mathrm{pH}$ for SARA (Cooper et al., 1999).

Rumen fluid was collected by manually taking 250 $\mathrm{g}$ each of digesta from 4 rumen sites (cranial ventral, caudal ventral, central, and cranial dorsal) as described by Duffield et al. (2004) $6 \mathrm{~h}$ after the first meal from Monday to Friday. On Wednesday through Thursday at $0300 \mathrm{~h}$ of every week during the experiment, rumen fluid samples were collected at 6 -h intervals just before feeding $(0 \mathrm{~h})$ and at 6,12 , and $18 \mathrm{~h}$ postfeeding. Wednesday was chosen for the intensive sampling because it marked the midpoint of the SARA treatment week. Samples from the different parts of the rumen were mixed thoroughly at each sampling time before $25 \mathrm{~mL}$ was transferred into sterilized centrifuge tubes and centrifuged for $30 \mathrm{~min}$ at $10,000 \times$ $g$. The supernatant was passed through a disposable $0.22-\mu \mathrm{m}$ sterile, pyrogen-free filter (Millex; Millipore Corporation, Bedford, MA). Samples were further heated at $100^{\circ} \mathrm{C}$ for $30 \mathrm{~min}$ before being stored at $-20^{\circ} \mathrm{C}$ for LPS determination as describe by Andersen (2000). The Limulus amoebocyte lysate (LAL) assay was used for LPS determination (Levin and Bang, 1964). The assay was performed using a 96 -well microplate kit
(Cambrex Bio Science Walkersville Inc., Walkersville, MD) with absorbance read at $405 \mathrm{~nm}$ on a microplate reader (model 3550; Bio-Rad, Hercules, CA). Detailed procedures for sample preparation and method validation have been described previously (Gozho et al., 2005).

A second portion of rumen fluid $(1.5 \mathrm{~mL})$ was not centrifuged but was mixed with an equal volume of glycerin in plastic tubes and stored at $-20^{\circ} \mathrm{C}$ until used for total coliform enumeration at a later stage. Total coliform counts were determined using modified chromogenic medium (Escherichia coli/coliform medium, cat. no. CM0956; Oxoid Inc., Nepean, ON, Canada) and buffered peptone water ( $\mathrm{pH} 7.2$, Difco Laboratories, Detroit, MI) as a diluent for serial dilutions of rumen fluid samples before plating. The chromogenic medium was modified by replacing $20 \%$ of the distilled water with clarified rumen fluid. The clarification process for the rumen fluid included centrifuging rumen fluid at $1,500 \times g$ for $10 \mathrm{~min}$, followed by autoclaving the supernatant at $121^{\circ} \mathrm{C}$ for $15 \mathrm{~min}$. Buffered peptone water (pH 7.2; Difco) was prepared according to the manufacturer's instructions. Carbon dioxide gas was bubbled through buffered peptone water and the chromogenic E. coli/coliform medium immediately after preparation and autoclaving to reduce the oxygen pressure (Bryant, 1972). Rumen fluid (100 $\mu \mathrm{L})$ was inoculated into $900 \mu \mathrm{L}$ of a $2 \%$ buffered peptone water in a 2 -mL sterile deep-well plate, thoroughly mixed by aspirating and dispensing the mixture several times, and then serially diluted to the appropriate dilution. Sterile pipette tips were used for each dilution. Drop plating was performed and 10 drops of $50 \mu \mathrm{L}$ each were pipetted (Repeater 4780; Eppendorf, Hamburg, Germany) onto the modified chromogenic medium that had been prepared previous and allowed to set. After the drops dried on the agar, the plates were inverted and incubated at $37^{\circ} \mathrm{C}$ for $18 \mathrm{~h}$. Colonies were manually counted and the appropriate dilution factor used to determine the number of coliforms from the undiluted rumen fluid sample. The countable dilution was determined as the dilution that gave 3 to 30 colonies per drop of sample dispensed.

The third portion of rumen fluid was centrifuged at $1,500 \times g$ for $10 \mathrm{~min}$ and the supernatant stored at $-20^{\circ} \mathrm{C}$ for the determination of the following VFA: acetic, propionic, butyric, isobutyric, isovaleric, and valeric acids. A day before analysis, rumen fluid samples were thawed at room temperature and $1 \mathrm{~mL}$ of a $25 \%$ meta-phosphoric acid solution was added to $5 \mathrm{~mL}$ of rumen fluid. The tubes containing the mixture were vortexed and frozen at $-20^{\circ} \mathrm{C}$ for $17 \mathrm{~h}$, after which samples were thawed and centrifuged for $10 \mathrm{~min}$ at $1,500 \times g$. Approximately $2 \mathrm{~mL}$ of supernatant was 
decanted into a clean, dry vial, which was capped and placed into the auto-sampler device (model 8100; Varian, Walnut Creek, CA). Concentrations of VFA were determined by GLC (model 3400 Star; Varian) using a 1.83-m glass column (model 2-1721; Supelco, Oakville, ON, Canada; Erwin et al., 1961).

Rectal temperature of the cows was measured at $1500 \mathrm{~h}$ from Monday to Friday as well as at 0900, 1500, 2100 , and $0300 \mathrm{~h}$ on Wednesday through Thursday using a digital thermometer (BD Flexible Digital, Franklin Lakes, NJ). The daily afternoon (1500 h) measurements coincided with the time when rumen $\mathrm{pH}$ was below 5.6 in SARA-treated cows and 6-hourly measurements on Wednesday were made to determine the effect of SARA induction on the diurnal variation of rectal temperature.

\section{Blood Sampling and Analyses}

Blood samples were collected into 4 blood tubes for each cow at 0900 and $1500 \mathrm{~h}$ on Wednesday during each period to coincide with the midpoint from SARA induction to end of each period. Samples were collected into two 10-mL serum tubes that were used for serum copper, fibrinogen, $\mathrm{Hp}$, and LPS analyses; one 10-mL sodium heparin-coated tube that was used for SAA analysis; and one 5 -mL tube coated with $\mathrm{K}_{3}$ EDTA for hematological analyses. The $\mathrm{K}_{3}$ EDTA tube and a serum tube were kept on ice during collection and were transported to the Manitoba Veterinary Services laboratory in Winnipeg, Manitoba, Canada. These samples were used for the determination of fibrinogen in serum by refractometry (George, 2001), copper concentration in serum by atomic absorption spectrophotometry (AA240FS; Varian; Meret and Henkin, 1971), and blood chemistry in the blood from the $\mathrm{K}_{3}$ EDTA tube. An automated hematology analyzer (Cell-Dyn 3500 system; Abbott Laboratories, Abbott Park, IL) was used for enumeration and delineation of white blood cells in whole blood from the $\mathrm{K}_{3}$ EDTA-coated tube. Leucocyte differentiation is based on multiple angle polarized scatter separation for this method (de Grooth et al., 1987; Terstappen et al., 1988) White blood cells were differentiated into neutrophils, eosinophils, lymphocytes, monocytes, basophils, and bands where present. Platelet count was done using the manual method of Brecher and Cronkite (1950).

The second serum sample was retained at our laboratory and used for LPS and Hp analyses. This sample was left to clot at room temperature $\left(\sim 18^{\circ} \mathrm{C}\right)$ for 45 min and subsequently centrifuged at $1,500 \times g$ for 30 min. A portion of the serum harvested was placed in pyrogen-free tubes, heated for $5 \mathrm{~min}$ at $100^{\circ} \mathrm{C}$, and stored at $-20^{\circ} \mathrm{C}$ until used for LPS analysis as de- scribed by Andersen et al. (1996). The other portion was stored in plastic tubes at $-20^{\circ} \mathrm{C}$ until used for $\mathrm{Hp}$ analysis. The sodium heparin-preserved blood sample was centrifuged at $1,500 \times \mathrm{g}$ immediately after collection. Plasma was harvested and stored at $-20^{\circ} \mathrm{C}$ for SAA analysis. Haptoglobin and SAA were determined in serum and plasma, respectively, using ELISA Tridelta Phase range assay kits (Tridelta Diagnostics Inc., Morris Plains, NJ; cat. nos. TP-801 and TP-802, respectively) as described by Gozho et al. (2005).

Serum LPS was determined using the LAL assay in samples after dilution 1:5 in pyrogen-free water. A metallo-modified polyanionic dispersant called Pyrosperse (Cambrex Bio Science Walkersville Inc.) was added to the samples before analysis. Pyrosperse is recommended by the manufacturer for use with serum to prevent LPS from binding to glass surfaces of test tubes during dilution. Serum LPS determination was performed using a 96-well microplate kit with absorbance read at $405 \mathrm{~nm}$ on a microplate reader (model 3550; Bio-Rad; Levin and Barg, 1964). Under these conditions, $83.2 \pm 18.1 \%$ (mean $\pm \mathrm{SD}$ ) of spike was recovered in positive control samples.

\section{Milk Yield and Composition}

Cows were milked twice daily in their stalls, and milk production was recorded at each milking. Four milk samples were collected into $50-\mathrm{mL}$ vials for each cow during two 24-h periods from Tuesday afternoon through to Thursday morning. Samples were preserved with 2-bromo-2-nitropropane-1,3 diol and stored at $4^{\circ} \mathrm{C}$ until analyzed by near infrared analysis for milk fat and milk protein content using the MilkO-Scan 303AB (Foss Electric, Hillerød, Denmark) at the laboratory of the Dairy Farmers of Manitoba (Winnipeg, MB).

\section{Statistical Analyses}

Data were analyzed using PROC MIXED (SAS Institute, 1996) as recommended by Wang and Goonewardene (2004) for the analysis of animal experiments with repeated measures. The effects of diet, time (hour or day), and their interactions were considered fixed, and week and cow effects were considered random. Tukey's multiple range test was used to separate means after a significant $(P \leq 0.05)$ treatment or time effect.

\section{RESULTS}

Dry matter intake was not different between the SARA and control cows. Average DM intakes were 18.0 


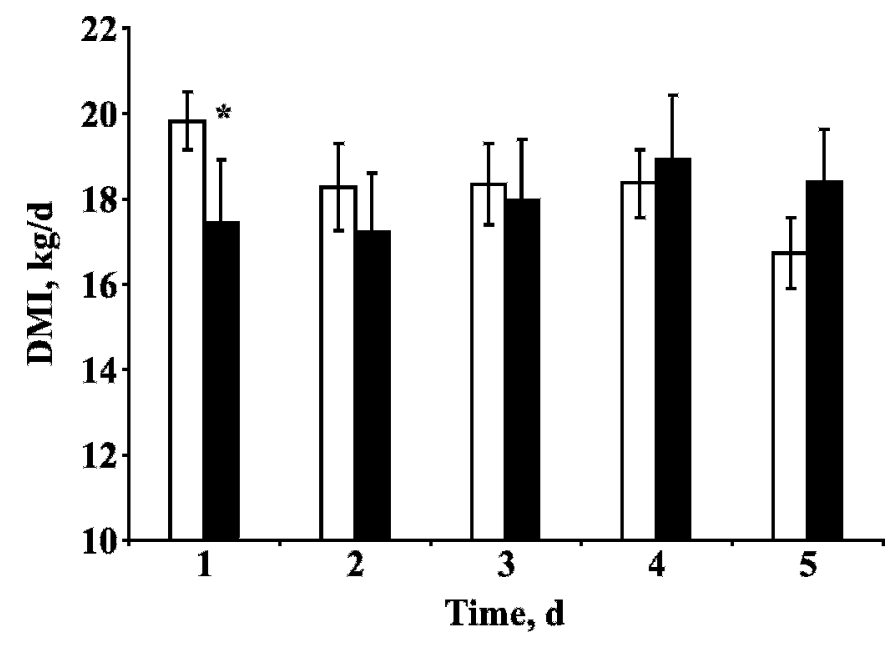

Figure 1. Total DM intake $(\mathrm{kg} / \mathrm{d})$ for dairy cows fed a TMR and wheat-barley pellets to induce subacute ruminal acidosis (SARA, $\square$ ) or the TMR only (control, $\mathbf{\square})$ in 2 cows in each treatment averaged across 4 wk. Each bar represents mean \pm SEM total DM intake. $* P$ $<0.05$, control vs. SARA.

and $18.3 \mathrm{~kg} / \mathrm{d}$ for the control and SARA treatments, respectively. On average, DM intake was higher $(P<$ $0.05)$ for SARA than control cows on the first day of SARA induction but was numerically lower $(P=0.14)$ on the last day of SARA induction (Figure 1). This resulted in a treatment $\times$ day interaction $(P<0.05)$ for both TMR and total DM intake (Table 2). Milk yield and milk composition are given in Table 2 . There were no differences in the yields of milk, fat, protein, or ECM between SARA treatment and control cows. However, milk fat was lower than milk protein content in all cows.

Inducing SARA decreased $(P<0.05)$ average daily rumen $\mathrm{pH}$ from 6.24 to 6.01 (Table 3 ) and increased $(P<0.05)$ the duration with $\mathrm{pH}$ below 6.0 from 459.5 to $741.9 \mathrm{~min} / \mathrm{d}$ and increased $(P<0.05)$ the duration with $\mathrm{pH}$ below 5.6 from 187.0 to $309.4 \mathrm{~min} / \mathrm{d}$. The area (time $\times \mathrm{pH})$ below $\mathrm{pH} 6.0$ increased $(P<0.05)$ from 145.7 to 278.7 , and the area (time $\times \mathrm{pH}$ ) below $\mathrm{pH} 5.6$ increased $(P<0.05)$ from 28.4 to 67.0 when SARA was induced (Table 3). Total VFA concentrations in the rumen were not affected by SARA induction and were 137.2 and $129.7 \mathrm{mM}$ for SARA and control cows, respectively (Table 4). Ruminal propionic acid concentration increased $(P<0.05)$ from $26.1 \mathrm{~m} M$ in control cows to $39.8 \mathrm{~m} M$ in SARA cows, which also led to lower $(P$ $<0.05$ ) acetate to propionate ratios for SARA cows compared with control cows (Table 4). Averaged across periods and treatments, the highest propionic and butyric acid concentrations were measured in rumen fluid collected at $2100 \mathrm{~h}$.

Averaged across sampling times, inducing SARA increased $(P<0.05)$ free ruminal LPS from 24,547 to $128,825 \mathrm{EU} / \mathrm{mL}$ (Table 5). There was a diurnal variation in free ruminal LPS. Averaged across treatments, the lowest concentrations were measured in samples collected at $1500 \mathrm{~h}$ (data not shown). The difference in free ruminal LPS between SARA and control cows in samples collected at $1500 \mathrm{~h}$ progressively increased up to the fourth day of treatment (Figure 2). Serum LPS concentration was below the detection limit of 0.1 $\mathrm{EU} / \mathrm{mL}$ for the LAL assay.

Table 2. Dry matter intake, milk yield, and composition of cows fed the control or subacute ruminal acidosis (SARA) diet ${ }^{1}$

\begin{tabular}{|c|c|c|c|c|c|c|}
\hline \multirow[b]{2}{*}{ Item $^{2}$} & \multicolumn{2}{|c|}{ Diet } & \multirow[b]{2}{*}{ SEM } & \multicolumn{3}{|c|}{$P$-value } \\
\hline & Control & SARA & & Diet & Day & Diet $\times$ Day \\
\hline TMR DM intake (kg/d) & $18.0^{\mathrm{a}}$ & $14.0^{\mathrm{b}}$ & 1.66 & $<0.0001$ & 0.12 & 0.003 \\
\hline TMR DM intake (\% of BW) & $3.37^{\mathrm{a}}$ & $2.60^{\mathrm{b}}$ & 0.26 & $<0.0001$ & $<0.01$ & 0.0004 \\
\hline Total DM intake $(\mathrm{kg} / \mathrm{d})$ & 18.0 & 18.3 & 1.64 & 0.74 & 0.04 & 0.002 \\
\hline Total DM intake (\% of BW) & 3.34 & 3.40 & 0.31 & 0.81 & 0.04 & 0.003 \\
\hline Milk yield $(\mathrm{kg} / \mathrm{d})$ & 27.5 & 28.6 & 1.83 & 0.27 & 0.81 & 0.69 \\
\hline $\mathrm{ECM}^{3}(\mathrm{~kg} / \mathrm{d})$ & 24.8 & 24.4 & 0.84 & 0.63 & 0.86 & 0.76 \\
\hline \multicolumn{7}{|l|}{ Milk components } \\
\hline Milk fat $(\%)$ & 2.49 & 2.21 & 0.23 & 0.45 & 0.70 & 0.08 \\
\hline Fat yield (kg/d) & 0.68 & 0.63 & 0.04 & 0.43 & 0.94 & 0.91 \\
\hline Milk protein $(\%)$ & 3.60 & 3.39 & 0.14 & 0.30 & 0.78 & 0.13 \\
\hline Milk protein (kg/d) & 1.01 & 0.98 & 0.08 & 0.77 & 0.86 & 0.76 \\
\hline
\end{tabular}

\footnotetext{
${ }^{\mathrm{a}, \mathrm{b}}$ Means within the same row followed by different superscript letters differ significantly $(P<0.05)$.

${ }^{1}$ Diets were a TMR only (control) or TMR $\pm 25 \%$ wheat barley concentrate.

${ }^{2}$ Dry matter intakes were calculated for 2 animals on each treatment averaged across periods $(\mathrm{n}=40)$ and for 4 animals averaged across periods and treatments for day effect $(\mathrm{n}=16)$; milk yield and composition were from samples collected on 2 days during each week $(n=12)$ for treatment and for day effects $(n=4)$ and analyzed by ANOVA.

${ }^{3} \mathrm{ECM}=$ milk corrected to $3.5 \%$ fat and 3.2 protein using the following equation: $\mathrm{ECM}, \mathrm{kg}=(12.82 \times \mathrm{kg}$ fat $)+(7.13 \times \mathrm{kg}$ protein $)+(0.323 \times \mathrm{kg}$ milk $)$; Tyrrell and Reid, 1965 .
} 
Table 3. Rumen $\mathrm{pH}$ variables of cows fed the control or subacute ruminal acidosis (SARA) $\operatorname{diet}^{1}$

\begin{tabular}{|c|c|c|c|c|c|c|}
\hline \multirow[b]{2}{*}{ Item $^{2}$} & \multicolumn{2}{|c|}{ Diet } & \multirow[b]{2}{*}{ SEM } & \multicolumn{3}{|c|}{$P$-value } \\
\hline & Control & SARA & & Diet & Day & Day $\times$ Diet \\
\hline Average $\mathrm{pH}$ & $6.24^{\mathrm{a}}$ & $6.01^{\mathrm{b}}$ & 0.065 & 0.0008 & 0.75 & 0.69 \\
\hline Time $<\mathrm{pH} 5.6, \mathrm{~min} / \mathrm{d}$ & $187.0^{\mathrm{b}}$ & $309.4^{\mathrm{a}}$ & 32.1 & $<0.0001$ & 0.59 & 0.99 \\
\hline Time $<\mathrm{pH} 6.0, \mathrm{~min} / \mathrm{d}$ & $459.5^{\mathrm{b}}$ & $741.9^{\mathrm{a}}$ & 61.5 & 0.0008 & 0.74 & 0.87 \\
\hline Area $<\mathrm{pH} 5.6, \min \times \mathrm{pH} / \mathrm{d}$ & $28.4^{\mathrm{b}}$ & $67.0^{\mathrm{a}}$ & 9.7 & 0.001 & 0.12 & 0.95 \\
\hline Area $<\mathrm{pH} 6.0, \min \times \mathrm{pH} / \mathrm{d}$ & $145.7^{\mathrm{b}}$ & $278.7^{\mathrm{a}}$ & 24.8 & $<0.0001$ & 0.48 & 0.98 \\
\hline
\end{tabular}

Rectal temperatures did not differ between treatments and were 38.4 and $38.5^{\circ} \mathrm{C}$ for control and SARA cows, respectively. Averaged across period and treatment, the lowest $(P<0.05)$ rectal temperatures were recorded at $1500 \mathrm{~h}$ within a 24-h period. Averaged across periods, white blood cell counts did not differ between treatments and were $5.69 \times 10^{9}$ and $5.23 \times$ $10^{9} / \mathrm{L}$. Haptoglobin, fibrinogen, and platelet counts did not differ between treatments and the respective concentrations in control and SARA cows were 0.24 and $0.27 \mathrm{mg} / \mathrm{mL}, 4.5$ and $5.0 \mathrm{mg} / \mathrm{mL}$, and $476 \times 10^{9}$ and $466 \times 10^{9} / \mathrm{L}$ for $\mathrm{Hp}$, fibrinogen, and platelet count, respectively. Serum copper concentrations did not differ between treatments but inducing SARA tended $(P=$ $0.07)$ to depress the serum copper concentration by $0.04 \mathrm{mg} / \mathrm{mL}$. Serum amyloid A increased $(P<0.05)$ from 286.8 to $498.8 \mu \mathrm{g} / \mathrm{mL}$ when SARA was induced.
Averaged across period and cows within treatment, coliform counts did not differ between treatments and were $6.77 \log _{10}\left(5.89 \times 10^{6}\right)$ and $6.72 \log _{10}\left(5.25 \times 10^{6}\right)$ $\mathrm{cfu} / \mathrm{mL}$ for control and SARA cows, respectively. However, coliform numbers were lower $(P=0.05)$ in SARA cows than in control cows for samples collected at 1500 h (Figure 3).

\section{DISCUSSION}

In this study, SARA was induced using the model developed by Keunen et al. (2002) and also used by Gozho et al. (2005, 2006). This model consists of replacing $25 \%$ of the DM intake from the base diet, which was the TMR in this study, with DM from grain pellets containing $50 \%$ ground wheat and $50 \%$ ground barley, and restricting the availability of TMR between 0900

Table 4. Volatile fatty acid concentration $(\mathrm{m} M)$ of rumen fluid of dairy cows fed the control and subacute ruminal acidosis (SARA) diets ${ }^{1}$

\begin{tabular}{|c|c|c|c|c|c|c|}
\hline \multirow[b]{2}{*}{ Variable $^{2}$} & \multicolumn{6}{|c|}{ VFA } \\
\hline & $\begin{array}{l}\text { Acetate } \\
\text { (A) }\end{array}$ & $\begin{array}{l}\text { Propionate } \\
\text { (P) }\end{array}$ & Butyrate & Other $^{3}$ & Total & A:P \\
\hline \multicolumn{7}{|c|}{ Time of day } \\
\hline $0900 \mathrm{~h}$ & 84.5 & $27.3^{\mathrm{b}}$ & $8.5^{\mathrm{c}}$ & $4.0^{\mathrm{a}}$ & 124.4 & $3.3^{\mathrm{a}}$ \\
\hline $1500 \mathrm{~h}$ & 84.5 & $34.8^{\mathrm{a}}$ & $11.0^{\mathrm{ab}}$ & $3.5^{\mathrm{ab}}$ & 133.8 & $2.7^{\mathrm{b}}$ \\
\hline $2100 \mathrm{~h}$ & 91.2 & $35.8^{\mathrm{a}}$ & $12.6^{\mathrm{a}}$ & $3.3^{\mathrm{b}}$ & 142.9 & $2.7^{\mathrm{b}}$ \\
\hline $0300 \mathrm{~h}$ & 85.5 & $33.9^{\mathrm{a}}$ & $9.8^{\mathrm{bc}}$ & $3.5^{\mathrm{ab}}$ & 132.7 & $2.7^{\mathrm{b}}$ \\
\hline SEM & 6.76 & 3.53 & 1.12 & 0.36 & 10.8 & 0.18 \\
\hline \multicolumn{7}{|l|}{ Diet $^{4}$} \\
\hline Control & 88.9 & $26.1^{\mathrm{b}}$ & 10.9 & $4.0^{\mathrm{a}}$ & 129.7 & $3.5^{\mathrm{a}}$ \\
\hline SARA & 84.0 & $39.8^{\mathrm{a}}$ & 10.1 & $3.2^{\mathrm{b}}$ & 137.2 & $2.2^{\mathrm{b}}$ \\
\hline SEM & 6.22 & 3.30 & 1.11 & 0.31 & 9.84 & 0.20 \\
\hline
\end{tabular}


Table 5. Ruminal LPS, rectal temperature, serum amyloid A, haptoglobin, and other blood chemistry variables in dairy cows fed the control or subacute ruminal acidosis (SARA) $\operatorname{diet}^{1}$

\begin{tabular}{|c|c|c|c|c|c|c|}
\hline \multirow[b]{2}{*}{ Item $^{2}$} & \multicolumn{2}{|c|}{ Diet } & \multirow[b]{2}{*}{ SEM } & \multicolumn{3}{|c|}{$P$-value } \\
\hline & Control & SARA & & Diet & Hour & Diet \pm Hour \\
\hline Ruminal LPS $\left(\log _{10} \mathrm{EU} / \mathrm{mL}\right)$ & $4.39^{\mathrm{b}}$ & $5.11^{\mathrm{a}}$ & 0.15 & $<0.0001$ & $<0.0001$ & 0.43 \\
\hline Rectal temperature $\left({ }^{\circ} \mathrm{C}\right)$ & 38.4 & 38.5 & 0.20 & 0.73 & 0.004 & 0.20 \\
\hline Serum amyloid $\mathrm{A}(\mu \mathrm{g} / \mathrm{mL})$ & $286.8^{\mathrm{b}}$ & $498.8^{\mathrm{a}}$ & 85.6 & 0.03 & 0.61 & 0.68 \\
\hline Haptoglobin $(\mathrm{mg} / \mathrm{mL})$ & 0.244 & 0.265 & 0.03 & 0.59 & 0.17 & 0.17 \\
\hline Fibrinogen $(\mathrm{mg} / \mathrm{mL})$ & 4.50 & 5.00 & 0.29 & 0.24 & 0.99 & 0.40 \\
\hline Serum copper $(\mu \mathrm{g} / \mathrm{mL})$ & 1.0 & 0.96 & 0.04 & 0.07 & 0.19 & 0.32 \\
\hline White blood cells $\left(\times 10^{9} / \mathrm{L}\right)$ & 5.69 & 5.23 & 0.28 & 0.25 & 0.28 & 0.22 \\
\hline Neutrophils (\% WBC) & 43.5 & 44.8 & 2.89 & 0.60 & 0.41 & 0.85 \\
\hline Eosinophils (\% WBC) & 3.20 & 2.29 & 0.39 & 0.10 & 0.53 & 0.90 \\
\hline Lymphocytes (\% WBC) & 46.10 & 45.49 & 2.61 & 0.57 & 0.65 & 0.91 \\
\hline Monocytes (\% WBC) & 6.50 & 6.08 & 1.01 & 0.68 & 0.46 & 0.93 \\
\hline Basophils (\% WBC) & 0.75 & 0.94 & 0.23 & 0.53 & 0.61 & 0.09 \\
\hline $\mathrm{Bands}^{3}$ (\% WBC) & 0.28 & 0.32 & 0.22 & 0.91 & 0.59 & 0.69 \\
\hline Platelets $\left(\times 10^{9} / \mathrm{L}\right)$ & 476 & 466 & 68.8 & 0.92 & 0.51 & 0.21 \\
\hline
\end{tabular}

\footnotetext{
${ }^{\mathrm{a}, \mathrm{b}}$ Means within the same row followed by different superscript letters differ significantly $(P<0.05)$.

${ }^{1}$ Diets were a TMR only (control) or TMR $\pm 25 \%$ wheat barley concentrate.

${ }^{2}$ Ruminal LPS concentration and rectal temperature were calculated for the animals on each treatment averaged across periods and times of sampling $(n=32)$ and for time intervals $(n=16)$; blood chemistry variables $(n=16)$ for treatment effects and $(n=32)$ for time intervals and were analyzed by ANOVA.

${ }^{3}$ Bands = immature white blood cells.
}

and $1700 \mathrm{~h}$. The use of this model resulted in an increase in the duration with rumen $\mathrm{pH}$ below 5.6 from 187 to $309 \mathrm{~min} / \mathrm{d}$. In previous studies (Gozho et al., 2005, 2006), our group concluded that SARA occurs when rumen $\mathrm{pH}$ is depressed below 5.6 for at least 180 $\mathrm{min} / \mathrm{d}$; hence, we were able to induce SARA in this study. However, control cows had an average duration

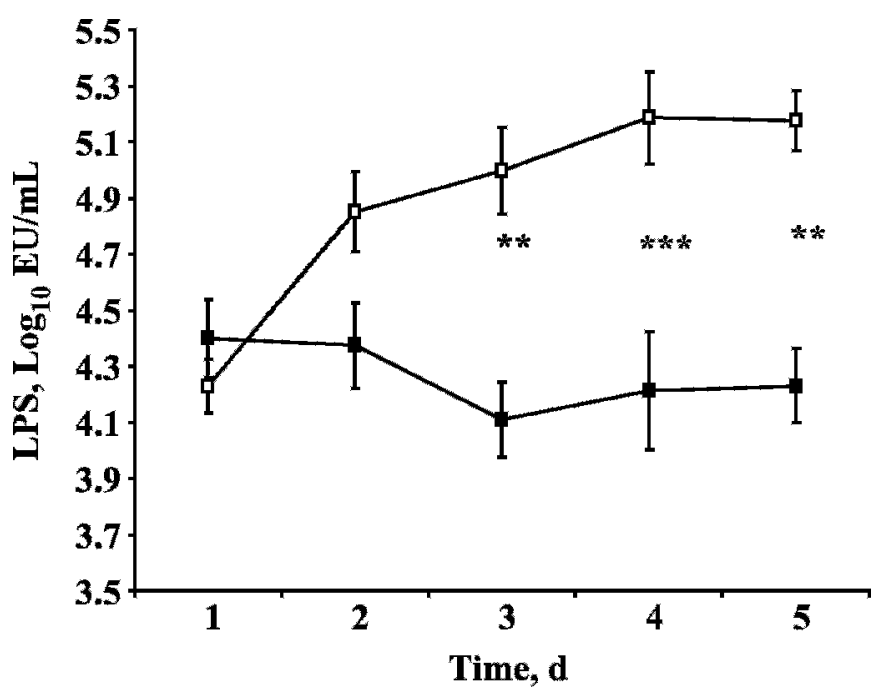

Figure 2. Ruminal LPS in dairy cows fed a TMR and wheat-barley pellets to induce subacute ruminal acidosis (SARA, $\square$ ) or the TMR only (control, - in 2 cows in each treatment averaged across $4 \mathrm{wk}$. Each bar represents mean \pm SEM. LPS concentration in $\log _{10}$ endotoxin units $(\mathrm{EU}) / \mathrm{mL}$. ${ }^{* *} P<0.01$, control vs. SARA; $* * * P<0.001$, control vs. SARA in samples collected at $1500 \mathrm{~h}$ every day. of rumen pH below 5.6 of $187 \mathrm{~min} / \mathrm{d}$. Both SARA and control cows had higher milk protein percentages than milk fat percentages. This inversion of milk fat and milk protein percentages is common in cows with ruminal acidosis (Nocek, 1997; Stone, 1999). Hence, milk composition and rumen $\mathrm{pH}$ suggest that these control cows also experienced ruminal acidosis, albeit a milder form of this disease than the SARA cows.

Beauchemin (1991) recommended that barley grainbased diets must contain at least $34 \% \mathrm{DM}$ of NDF to

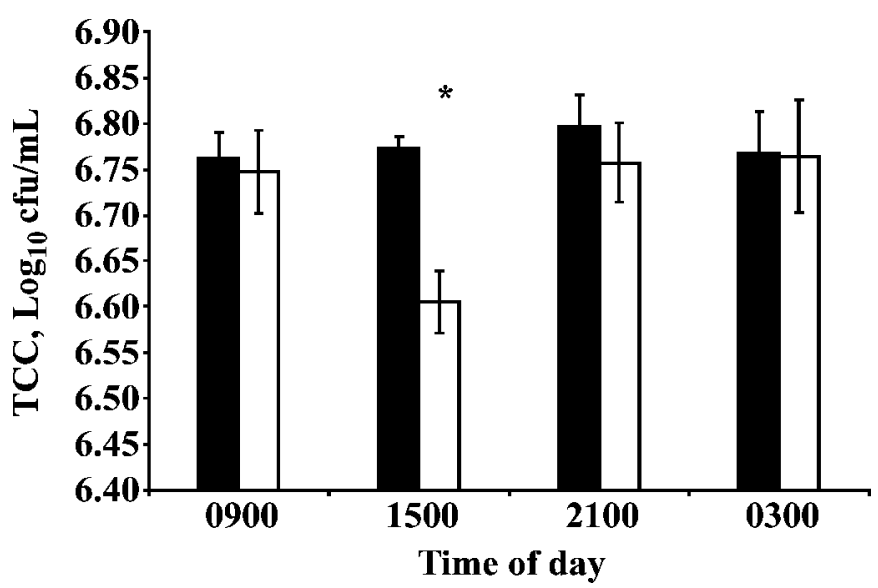

Figure 3. Total coliform counts (TCC, $\log _{10} \mathrm{cfu} / \mathrm{mL}$ ) in rumen fluid from cows fed a TMR and wheat-barley pellets to induce subacute ruminal acidosis (SARA, $\square$ ) or the TMR only (control, $\mathbf{\square}$ ). The TCC were enumerated in rumen fluid that was collected at 6 -h intervals over $2 \mathrm{~d}$ in each week; values are averages of $4 \mathrm{wk}$. Each bar represents mean \pm SEM. $* P<0.05$, control vs. SARA. 
prevent SARA. Although the TMR was formulated to meet this recommendation, analysis of the diets revealed that NDF content was $31.1 \%$ DM. Hence, the low $\mathrm{pH}$ in the cows receiving the control diet might have been due to the low NDF content of the diet. Another contributing factor to the low rumen $\mathrm{pH}$ in the control cows could be the high DM of the TMR (63.4\%). High TMR DM content has been associated with increased sorting (Leonardi et al., 2005), which would reduce NDF intake and milk fat percentage. However, because sorting was not determined in this study, we could not prove this assumption.

Replacing TMR with pellets increased the concentrate content of the diet to $67 \%$, further reducing rumen buffering, and probably reduced saliva flow (Maekwa et al., 2002), leading to longer periods with $\mathrm{pH}$ below 5.6 in SARA cows. Total VFA concentrations in our experiment were similar to those observed in dairy steers in which SARA was induced after adaptation to a $61 \%$ wheat-barley concentrate diet (Gozho et al., 2006).

Milk fat content depression is commonly associated with SARA (Nocek, 1997). Milk composition did not differ between SARA and controls in the current study. This might have been due to the low $\mathrm{pH}$ in the cows receiving the control diet. Reports in the literature indicate that milk fat depression does not always accompany SARA. Cottee et al. (2004) and Keunen et al. (2002) did not observe changes in milk fat content when SARA was induced, but Krause et al. (2002) found a positive correlation between mean rumen $\mathrm{pH}$ and milk fat content and a negative correlation between time with $\mathrm{pH}$ below 5.8 and milk fat content. It has also been suggested that the inconsistent response in milk fat in experimentally induced SARA may be related to the duration of the bout(s) of SARA, with short periods likely having no effect on milk fat content (Krause and Oetzel, 2005). In the present study, milk fat was lower than milk protein in both treatments, which suggests that there was an imbalance between effective fiber and starch sources in both diets (Slater et al., 2000). This is also supported by the rumen $\mathrm{pH}$ data that showed that cows in both treatment groups experienced SARA.

Free ruminal LPS was $4.39 \log _{10}(24,547) \mathrm{EU} / \mathrm{mL}$ in the cows on the control diet and this was higher than either $3.57 \log _{10}(3,715)$ or $3.80 \log _{10}(6,310) \mathrm{EU} / \mathrm{mL}$ in steers on forage diets in studies by Gozho et al. (2005) and Gozho et al. (2006), respectively. Inducing SARA in steers adapted to a hay diet or after gradual adaptation to a $61 \%$ concentrate diet increased ruminal LPS by 8,874 and $8,718 \mathrm{EU} / \mathrm{mL}$, respectively (Gozho et al., 2005, 2006). However, free ruminal LPS concentration increased by a greater magnitude in the present study than in the studies with the steers. The results from these 3 studies show that feeding concentrate increases ruminal LPS and that the magnitude of the response depends on the level of concentrate in the diet and probably how long such diets are fed before inducing SARA.

There is a paucity of data on the effects of SARA on free ruminal LPS or the effects of SARA on gramnegative bacteria species in the rumen on microbial populations in the rumen. Studies by Nagaraja et al. (1978) used lethal dose 50\% $\left(\mathrm{LD}_{50}\right)$ to determine the amount of free ruminal LPS. Andersen et al. (1994) reported free ruminal LPS concentrations of 118 to $148 \mathrm{EU} / \mathrm{mL}$ in hay-fed nonlactating dairy cows and the concentrations increased to $1,500 \mathrm{EU} / \mathrm{mL}$ during grain adaptation. Andersen and Jarlov (1990) reported free ruminal LPS concentrations that ranged from 1,500 to $1,600 \mathrm{EU} / \mathrm{mL}$ in hay-fed nonlactating dairy cows during grain engorgement. The LAL assay was used in both these studies to determine LPS. However, few animals were used in these studies and hence deficiencies in experimental design and experimental units precluded statistical analyses on these data. Additionally, grain engorgement in these studies resulted in acute acidosis and hence may not be representative of microbiological changes that could result from SARA.

Rapid growth of bacteria is associated with bacterial lysis due to excessive activity of autolytic enzymes during cell growth and division in the rapid growth phase (Wells and Russell, 1996). It has been suggested that as much as $60 \%$ of ruminal LPS is produced by rapidly growing gram-negative bacteria (Andersen, 2000). Introducing large proportions of NSC in the diet will alter populations of rumen bacteria (Tajima et al., 2001). In the present study, the basal diet already contained $37.2 \%$ of NSC, which led to long periods when bacteria could grow rapidly and shed LPS into rumen fluid. Because the TMR and wheat barley pellets were offered at different times, this ensured that NSC availability for rumen microbial growth was staggered and was available for longer times in SARA cows than controls. The total NSC content from TMR and pellets in the SARA diet was $43.5 \%$. Within a 24 -h period, total coliform counts were lowest in SARA cows in rumen fluid collected at $1500 \mathrm{~h}$, which may imply a slower growth rate in gram-negative bacteria during this time compared with all other sampling times.

Subacute ruminal acidosis can result in damage to the rumen epithelium, which leads to pathogen infiltration and subsequently to abscessation of various organs in the body (Nordlund et al., 1995). The presence of pathogens and LPS in blood circulation sets off inflammatory responses (Andersen, 2000). In the 
present study, LPS was not detected in peripheral blood circulation. Using LAL assay qualitative techniques, Dougherty et al. (1975) and Aiumlamai et al. (1992) reported the presence of LPS but Andersen and Jarlov (1990) and Andersen et al. (1994) did not detect LPS in peripheral blood circulation when acute acidosis was induced. Free ruminal LPS that is translocated into the hepatic portal circulation can be detoxified by the liver before it reaches the peripheral blood circulation (Andersen, 2000). However, the majority of cytokine receptors are found in the Kupffer cells in the liver (Bode and Heinrich, 2001) and therefore the first wave of proinflammatory cytokines may be initiated before detoxification.

The proportion of white blood cells did not differ between treatments and were within normal range for cows (Kahn and Line, 2003). Rectal temperature was recorded to determine if a febrile response is associated with SARA. Previous studies by Andersen (2000) do not support that higher than normal body temperature is a consistent clinical sign in ruminal acidosis-related endotoxemia (Andersen, 2000). Copper concentration was measured in serum because it is an integral component of ceruloplasmin, and ceruloplasmin activity correlates closely with serum or plasma copper concentrations (Blakley and Hamilton, 1985). Therefore, serum copper was used as an indirect measure of ceruloplasmin concentrations in control and SARA cows.

In the present study, SAA in control cows was higher than that in steers with grain-induced SARA (Gozho et al., 2006). This agrees with the rumen $\mathrm{pH}$ data that show that both control and SARA cows had a rumen $\mathrm{pH}$ below 5.6 for more than $3 \mathrm{~h} / \mathrm{d}$. In previous studies, Hp concentrations increased when SARA was induced in hay- and concentrate-adapted steers, respectively (Gozho et al., 2005, 2006). Haptoglobin concentrations greater than $0.2 \mathrm{mg} / \mathrm{mL}$ suggest early or mild infection in cattle (Skinner et al., 1991). In the present study, Hp concentrations were 0.24 and $2.70 \mathrm{mg} / \mathrm{mL}$ for control and SARA cows and were therefore above the threshold suggested by Skinner et al. (1991). Hence, the data obtained in the present study suggest that inflammation occurred in both control and SARA cows. The disparity in the concentrations of $\mathrm{Hp}$ and SAA cows with SARA could be due to a difference in the cytokines involved in initiating the synthesis of these acute phase proteins (Jacobsen et al., 2004). Serum amyloid A synthesis can be induced by the release of either IL-6 or tumor necrosis factor- $\alpha$ but both these cytokines are required for haptoglobin to be synthesized (Alsemgeest et al., 1996). Therefore, the combination of cytokines required for SAA synthesis may be different from the combination that activates haptoglobin synthesis (Jacobsen et al., 2004). The cows in the current experiment had received a high concentrate diet for at least $17 \mathrm{wk}$ before the study. As a result, cows might have suffered from chronic SARA, whereas the steers in our earlier studies (Gozho et al., 2006) experienced acute SARA. The reasons the combinations of cytokines to activate $\mathrm{Hp}$ synthesis were not synthesized in dairy cows with chronic inflammation in this study are presently not known. Serum amyloid A is considered to be the more sensitive acute phase protein and to respond faster to inflammation stimuli because it is detected earlier in blood than haptoglobin (Alsemgeest et al., 1994; Horadagoda et al., 1994).

Further research is required to determine cytokine and acute phase protein responses as a result of acute or chronic SARA. This is because chronic inflammation most likely results from SARA that occurs in dairy cows compared with the acute inflammation that results from experimentally induced SARA, and the cytokines released during a chronic type of SARA may differ from that induced experimentally, particularly in cattle that have been on high roughage diets.

\section{CONCLUSIONS}

Grain-induced SARA increased free ruminal LPS concentration in mid lactation in dairy cows, but did not result in detectable LPS in peripheral blood. Induction of SARA increased the duration with $\mathrm{pH}$ below 5.6 from 187.0 to $309.4 \mathrm{~min} / \mathrm{d}$. Milk yield and milk composition did not differ between control and SARA cows, but there was a milk fat to protein inversion in cows from both treatments. This milk fat to protein inversion and the duration of $\mathrm{pH}$ below 5.6 in control cows suggest that these cows also experienced ruminal acidosis, albeit in a milder form than the SARA cows. Inducing SARA increased SAA from 286.88 to 498.8 $\mu \mathrm{g} / \mathrm{mL}$. The concentrations of SAA are consistent with an inflammatory response in both control and SARA cows and also show that concentrations of SAA increase in proportion to the duration with $\mathrm{pH}$ below 5.6. Haptoglobin, serum copper, fibrinogen concentrations, and white blood cell profiles did not change in cows with SARA, possibly because these markers were only determined in blood samples collected on one day that was midpoint between the beginning of SARA induction and the end of the SARA period.

\section{ACKNOWLEDGMENTS}

The Natural Sciences and Engineering Research Council of Canada (NSERC) is sincerely thanked for funding the project (to JCP) and the Cyril L. AndersonRidley Canada Limited Graduate Fellowship in Ani- 
mal Nutrition is acknowledged for financial support (to GNG). Frank Juck of Manitoba Veterinary Services is thanked for advice with fibrinogen, serum copper, and hematological analyses. We also thank Dale Rosner and staff at Glenlea Research Station for looking after the animals; Terri Garner, Deanne Fulawka, Akbar Nikkhah, Ehsan Khafipoor, and Sanjiv Bandari for technical assistance; and Gary Crow and Loreen Onischuk for help with statistical analyses.

\section{REFERENCES}

Aiumlamai, S., H. Kindahl, G. Fredriksson, L. E. Edqvist, L. Kulander, and O. Eriksson. 1992. The role of endotoxins in induced ruminal acidosis in calves. Acta Vet. Scand. 33:117-127.

Alsemgeest, S. P., H. C. Kalsbeek, T. Wensing, J. P. Koeman, A. M. van Ederen, and E. Gruys. 1994. Concentrations of serum amyloid-A (SAA) and haptoglobin ( $\mathrm{Hp}$ ) as parameters of inflammatory diseases in cattle. Vet. Q. 16:21-23.

Alsemgeest, S. P. M., G. A. E. Vant Klooster, A. S. J. P. A. M. van Miert, C. K. Hulskamp-Koch, and E. Gruys. 1996. Primary bovine hepatocytes in the study of cytokine induced acute-phase protein secretion in vitro. Vet. Immunol. Immunopathol. 53:179-184.

Andersen, P. H. 2000. Bovine endotoxicosis: Aspects of relevance to ruminal acidosis. Dr. Vet. Sci. Thesis, The Royal Veterinary and Agricultural University, Copenhagen, Denmark.

Andersen, P. H., B. Bergelin, and K. A. Christensen. 1994. Effect of feeding regimen on concentration of free endotoxin in ruminal fluid of cattle. J. Anim. Sci. 72:487-491.

Andersen, P. H., and N. Jarlov. 1990. Investigation of the possible role of endotoxin, TXA2, PG12 and PGE2 in experimentally induced rumen acidosis in cattle. Acta Vet. Scand. 31:27-38.

Andersen, P. H., N. Jarlov, M. Hesselholt, and L. Baek. 1996. Studies on in vivo endotoxin plasma disappearance times in cattle. J. Vet. Med. A. 43:93-101.

Arthington, J. D., A. R. Spell, L. R. Corah, and F. Blecha. 1996. Effect of molybdenum-induced copper deficiency on in vivo and in vitro measures of neutrophil chemotaxis both before and following an inflammatory stressor J. Anim. Sci. 74:2759-2764.

Beauchemin, K. A. 1991. Effects of dietary neutral detergent fiber concentration and alfalfa hay quality on chewing, rumen function, and milk production of dairy cows. J. Dairy Sci. 74:3140-3151.

Blakley, B. R., and D. L. Hamilton. 1985. Ceruloplasmin as an indicator of copper status in cattle and sheep. Can. J. Comp. Med. 49:403-408.

Bode, J. G., and P. C. Heinrich. 2001. Interleukin-6 signaling during the acute-phase response of the liver. Pages 565-580 in The Liver, Biology and Pathobiology. 4th ed. I. M. Arias, J. L. Boyer, F. V. Chisari, N. Fausto, D. Schachter, and D. A. Shafritz, ed. Lippincott Williams and Wilkins, Philadelphia, PA.

Brecher, G., and E. P. Cronkite. 1950. Morphology and enumeration of human blood platelets. J. Appl. Physiol. 3:365-377.

Bryant, M. P. 1972. Commentary on the Hungate technique for culture of anaerobic bacteria. Am. J. Clin. Nutr. 25:1324-1328.

Calsamiglia, S., A. Ferret, and M. Devant. 2002. Effect of $\mathrm{pH}$ and $\mathrm{pH}$ fluctuations on microbial fermentation and nutrient flow from a dual-flow continuous culture system. J. Dairy Sci. 85:574-579

Canadian Council on Animal Care. 1993. Guide to the Care and Use of Experimental Animals. Vol. 1. E. D. Olfert, B. M. Cross, and A. A. McWilliam, ed. CCAC, Ottawa, ON, Canada.

Conner, J. G., P. D. Eckersall, A. Wiseman, T. C. Aitchison, and T. A. Douglas. 1988. Bovine acute phase response following turpentine injection. Res. Vet. Sci. 44:82-88.

Cooper, R. J., T. J. Klopfenstein, R. A. Stock, C. T. Milton, D. W. Herold, and J. C. Parrott. 1999. Effects of imposed feed intake variation on acidosis and performance of finishing steers. J. Anim. Sci. 77:1093-1099.

Cottee, G., I. Kyriazakis, T. M. Widowski, M. I. Lindinger, J. P. Cant, T. F. Duffield, V. R. Osborne, and B. W. McBride. 2004. The effects of subacute ruminal acidosis on sodium bicarbonatesupplemented water intake for lactating dairy cows. J. Dairy Sci. 87:2248-2253.

de Grooth, B. G., L. W. M. M. Terstappen, G. J. Puppels, and J. Greve. 1987. Light-scattering polarization measurements as a new parameter in flow cytometry. Cytometry 8:539-544.

Dougherty, R. W., K. S. Coburn, H. M. Cook, and M. Allison. 1975. A preliminary study of the appearance of endotoxin in the circulatory system of sheep and cattle after induced grain-engorgement. Am. J. Vet. Res. 36:831-832.

Duffield, T., J. C. Plaizier, A. Fairfield, R. Bagg, G. Vessie, P. Dick, J. Wilson, J. Aramini, and B. McBride. 2004. Comparison of techniques for measurement of rumen $\mathrm{pH}$ in lactating dairy cows. J. Dairy Sci. 87:59-66.

Erwin, E. S., G. J. Marco, and E. M. Emery. 1961. Volatile fatty acids analysis of blood and rumen fluid by gas chromatography. J. Dairy Sci. 44:1768-1776.

Garrett, E. F., K. V. Nordlund, W. J. Goodger, and G. R. Oetzel. 1997. A cross-sectional field study investigating the effect of periparturient dietary management on ruminal $\mathrm{pH}$ in early lactation dairy cows. J. Dairy Sci. 80(Suppl. 1):169. (Abstr.)

George, J. W. 2001. The usefulness and limitations of hand-held refractometers in veterinary medicine: An historical and technical review. Vet. Clin. Pathol. 30:201-210.

Gozho, G. N., J. C. Plaizier, and D. O. Krause. 2006. Ruminal lipopolysaccharide concentration and inflammatory response during gradual stepwise adaptation to concentrate and subsequent induction of subacute ruminal acidosis in steers. J. Dairy Sci. 89:4404-4413.

Gozho, G. N., J. C. Plaizier, D. O. Krause, A. D. Kennedy, and K. M. Wittenberg. 2005. Subacute ruminal acidosis induces ruminal lipopolysaccharide endotoxin release and triggers an inflammatory response J. Dairy Sci. 88:1399-1403.

Hirvonen, J. 2000. Hirvonen's thesis on acute phase response in dairy cattle. S. Pyörälä, ed. University of Helsinki, Finland.

Horadagoda, A., P. D. Eckersall, J. C. Hodgson, H. A. Gibbs, and G. M. Moon. 1994. Immediate responses in serum TNF alpha and acute phase protein concentrations to infection with Pasteurella haemolytica A1 in calves. Res. Vet. Sci. 57:129-132.

Horadagoda, N. U., K. M. G. Knox, H. A. Gibbs, S. W. J. Reid, A. Horadagoda, S. E. R. Edwards, and P. D. Eckersall. 1999. Acute phase proteins in cattle: Discrimination between acute and chronic inflammation. Vet. Rec. 144:437-441.

Jacobsen, S., P. H. Andersen, T. Toelboell, and P. M. H. Heegaard. 2004. Dose dependency and individual variability of the lipopolysaccharide-induced bovine acute phase protein response. J. Dairy Sci. 87:3330-3339.

Kahn, C. M., and S. Line. 2003. Hematologic reference ranges. The Merck Veterinary Manual. 8th ed (online). Merck and Co. Inc., Whitehouse Station, NJ.

Keunen, J. E., J. C. Plaizier, L. Kyriazakis, T. F. Duffield, T. M. Widowski, M. I. Lindinger, and B. W. McBride. 2002. Effects of a subacute ruminal acidosis model on the diet selection of dairy cows. J. Dairy Sci. 85:3304-3313.

Krause, K. M., D. K. Combs, and K. A. Beauchemin. 2002. Effects of forage particle size and grain fermentability in midlactation cows. II. Ruminal $\mathrm{pH}$ and chewing activity J. Dairy Sci. 85:1947-1957.

Krause, K. M., and G. R. Oetzel. 2005. 2005. Inducing subacute ruminal acidosis in lactating dairy cows. J. Dairy Sci. 88:3633-3639.

Leonardi, C., F. Giannico, and L. E. Armentano. 2005. Effect of water addition on selective consumption (sorting) of dry diets by dairy cattle. J. Dairy Sci. 88:1043-1049.

Levin, J., and F. B. Bang. 1964. A description of cellular coagulation in the Limulus. Bull. Johns Hopkins Hosp. 115:337-345.

Maekwa, M., K. A. Beauchemin, and D. A. Christensen. 2002. Effect of concentrate level and feeding manangement on chewing activ- 
ities, saliva production, and ruminal $\mathrm{pH}$ of lactating dairy cows. J. Dairy Sci. 85:1165-1175.

Meret, S., and R. I. Henkin. 1971. Simultaneous direct estimation by atomic absorption spectrophotometry of copper and zinc in serum, urine, and cerebrospinal fluid. Clin. Chem. 17:369-373.

Nagaraja, T. G., E. E. Bartley, L. R. Fina, and H. D. Anthony. 1978. Relationship of rumen gram-negative bacteria and free endotoxin to lactic acidosis in cattle. J. Anim. Sci. 47:1329-1336.

Nocek, J. E. 1997. Bovine acidosis: Implications on laminitis. J. Dairy Sci. 80:1005-1028.

Nordlund, K. V., E. F. Garrett, and G. R. Oetzel. 1995. Herd-based rumenocentesis: A clinical approach to the diagnosis of subacute rumen acidosis. Compend. Contin. Educ. Pract. Vet. Food Anim. $17:$ s48-s56.

SAS Institute. 1996. SAS System for Mixed Models. 4th ed. SAS Inst., Inc., Cary NC.

Skinner, J. G., R. A. L. Brown, and L. Roberts. 1991. Bovine haptoglobin response in clinically defined field conditions. Vet. Rec. 128:147-149.

Slater, A. L., M. L. Eastridge, J. L. Firkins, and L. J. Bidinger. 2000. Effects of starch source and level of forage neutral detergent fiber on performance by dairy cows. J. Dairy Sci. 83:313-321.
Stone, W. C. 1999. The effect of subclinical rumen acidosis on milk components. Pages 40-46 in Proc. Cornell Nutr. Conf. Feed Manuf. Cornell Univ., Ithaca, NY.

Tajima, K., R. I. Aminov, T. Nagamine, H. Matsui, M. Nakamura, and Y. Benno. 2001. Diet-dependent shifts in the bacterial population of the rumen revealed with real-time PCR. Appl. Environ. Microbiol. 67:2766-2774.

Terstappen, L. W. M. M., B. G. de Grooth, K. Visscher, F. A. van Kouterik, and J. Greve. 1988. Four parameter white blood cell differential counting based on light scattering measurements. Cytometry 9:39-43.

Tyrrell, H. F., and J. T. Reid. 1965. Prediction of the energy value of cow's milk. J. Dairy Sci. 48:1215-1223.

Wang, Z., and L. A. Goonewardene. 2004. The use of MIXED models in the analysis of animal experiments with repeated measures data. Can. J. Anim. Sci. 84:1-11.

Wells, J. E., and J. Russell. 1996. The effect of growth and starvation on the lysis of the ruminal cellulolytic bacterium Fibrobacter succinogenes. Appl. Environ. Microbiol. 62:1342-1346.

Werling, D., F. Sutter, M. Arnold, G. Kun, P. C. J. Tooten, E. Gruys, M. Kreuzer, and W. Langhans. 1996. Characterisation of the acute phase response of heifers to a prolonged low dose infusion of lipopolysaccharide. Res. Vet. Sci. 61:252-257. 